\title{
Stopy l’udského ohryzu na kostiach (Pilotná experimentálna analýza)
}

\author{
Michaela Stančíková ${ }^{1}$, Sandra Sázelová ${ }^{1,2}$ \\ 1 Ústav antropologie Př́rodovědecké fakulty Masarykovy univerzity, Kotlářská 2, 61137 Brno \\ 2 Středisko pro paleolit a paleoetnologie Archeologického ústavu AVČR, Brno, Dolní Věstonice 25, 69129 Dolní Věstonice
}

Do redakce doručeno 14. května 2015; k publikaci přijato 7. března 2016

\section{HUMAN GNAW MARKS ON BONES (PILOT EXPERIMENTAL ANALYSIS)}

ABSTRACT In anthropological and archeological context the human gnaw marks produce information about the socio-cultural background of studied recent and ancient communities, especially in their dining attitudes and habits. Our paper presents a selected published methodologies used to study this topic and tests the human gnaw marks on experimental sample from Slovak Republic. This sample with 40 volunteers was divided into two groups - one was informed about the aim of the experimental project and the other remained uninformed. The prevalence of pits and scores caused by human incisors was recorded, followed by notches after secondary butchering processes (observed in both samples) and cut marks after table-knives (observed only in one sample). Finally, we have to admit, that according to the inter-sample analysis the style of dining and eating habits perhaps affects the appearance and stage of damages caused by human teeth.

KEY WORDS human gnaw marks; experimental study; Slovak Republic; dining and eating habits

\begin{abstract}
ABSTRAKT Stopy ludského ohryzu sú v archeologickom a antropologickom kontexte zdrojom informácií o socio-kultúrnom pozadí skúmanej súčasnej i minulej spoločnosti, ich stravovacej kultúre a návykoch. Tento článok prezentuje výber z už publikovaných metodík používaných pri štúdiu tejto témy a testuje stopy ludského ohryzu na experimentálnej vzorke zo Slovenskej republiky. Vzorka so 40 dobrovolníkmi bola rozdelená do dvoch skupín- jedna skupina bola informovaná o cieloch experimentálneho projektu a druhá skupina ostala neinformovaná. Prevažne boli zaznamenané jamky a škrabance spôsobené rezákmi, nasledovali škrabance ako pozostatky sekundárneho spracovania (pozorované v oboch súboroch) a zárezy po príborovom noži (pozorované len v jednom súbore). Podla analýzy vzoriek navzájom pripúštame možnost', že štýl stravovania a stravovacích návykov ovplyvňuje výskyt a rozsah poškodení spôsobených ludskými zubami.
\end{abstract}

KL'ÚČOVÉ SLOVÁ stopy ludského ohryzu; experimentálna štúdia; Slovenská republika; jedálne a stravovacie návyky

\section{ÚVOD DO PROBLEMATIKY LUDSKÉHO OHRYZU}

Stopy ludského ohryzu a okusu nachádzané na kostennom materiále sú pre archeológov a antropológov dôležitým tafonomickým faktorom, nasvedčujúcim o ekonomicko-subsistenčnom, ale aj symbolickom aspekte ludského správania. Oblast' výskumu ludského ohryzu na kostiach tak skrýva vel'ký potenciál ako na poli antropológie, tak i archeológie, pretože prostredníctvom ohryzu na kostiach je možné dokumentovat' stopy od stravovacích návykov (Pobiner 2008,
373), cez vzájomné prekryvy s ostatnými živočćšnymi taxónmi (Martínez 2009, 17, Binford, 1981, 49) až po prípadnú antropofágiu (Fernández-Jalvo, Andrews 2011, 117). Problémom však je, že napriek snahe odborníkov stále neexistuje klúč, podla ktorého by bolo možné s istotou odlíšit poškodenia spôsobené ludským ohryzom od niektorých iných tafonomických faktorov, napríklad ohryzu šeliem a i. (Elkin, Mondini 2000, 256). Avšak vzájomné odlíšenie bolo už na konci 70. rokov 20. storočia považované za klúčové napríklad v diskusii lovu u raných hominidov a ich konkurencie 


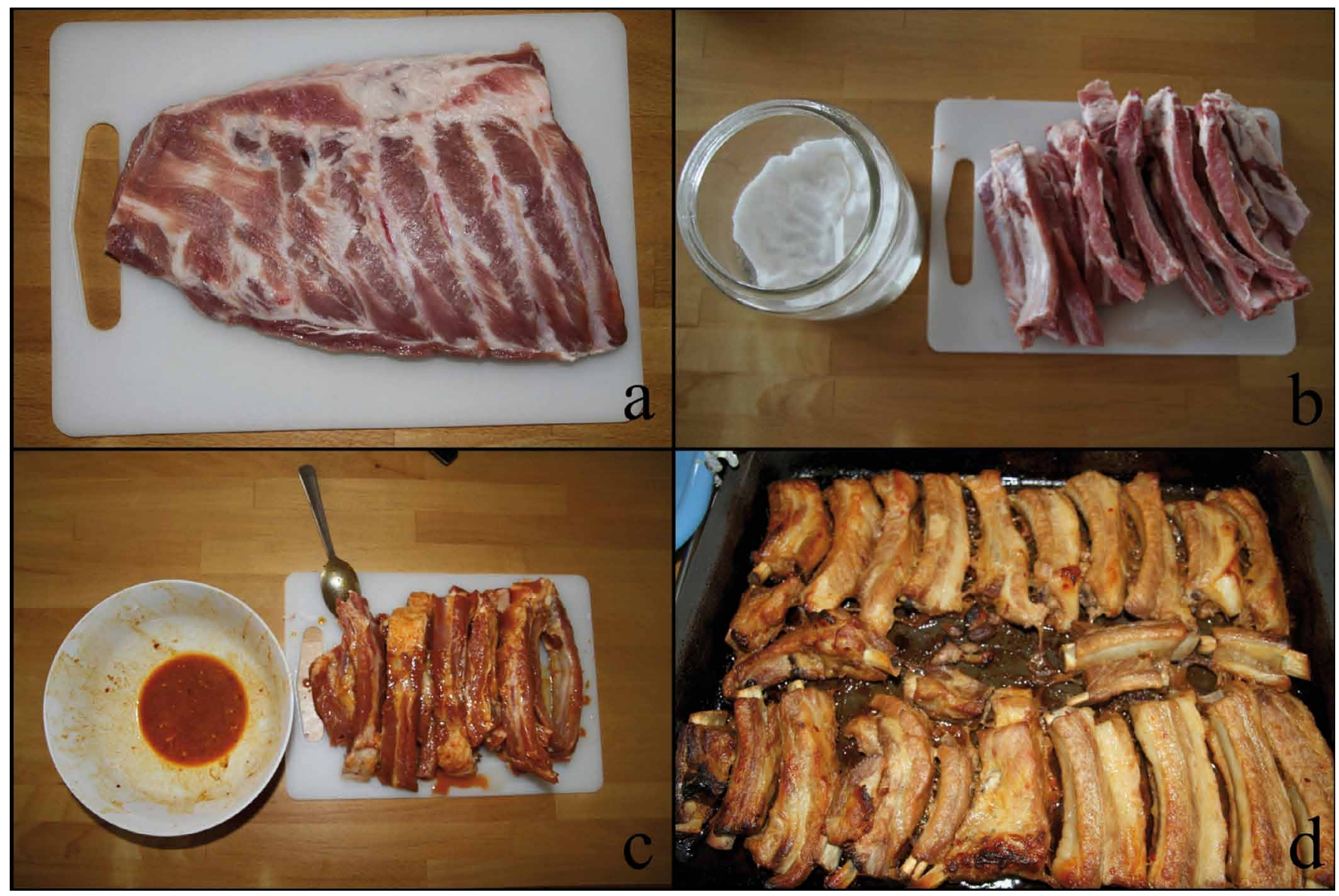

Obr. 1. Postup prípravy bračových rebierok z prvého súboru na konzumáciu, a - surový blok bravčových rebier, b -naporcované rebrá solené, c - marinované rebrá, d - pečené rebrá. Foto M. Stančíková.

schopnosti šelmám, a preto sa štúdiu stôp ludského ohryzu na kostiach ako jeden z prvých začal venovat L.R.Binford, ktorý vo svojich etnoarcheologických publikáciách (1978, 1981) poukázal na špecifické rozdrvené okraje kostí od Inuitov. U dlhších kostí, akými sú napríklad rebrá, si u Nunamiutov všimol, že žuvanie a cucanie je viazané pomerne striktne na laterálne konce kostí, naopak poškodenia ako jamky či škrabance sa na laterálnych koncoch nenachádzajú. Tieto znaky potom Binford porovnával s tými po mäsožravcoch (Binford 1978, 149; 1981, 36). V novšej štúdii M. Domínguez-Rodriga a R. Barbu (2006), ktorá sa venovala preskúmaniu kostrového materiálu $\mathrm{z}$ oblasti FLK Zinj za účelom zistenia, $\mathrm{v}$ akom poradí sa $\mathrm{k}$ potrave dostávali mäsožravce a hominidi, došlo k zisteniu, že na vzorke, ktorú predtým študovali viacerí odborníci, sa síce nachádzajú povrchové modifikácie podobné zubom, no ich vznik bol podmienený biochemickýmim procesmi. Okrem toho pri skúmaní materiálu autori zistili, že frekvencia výskytu stôp po zuboch je ovela nižšia, než bola dokumentovaná predchádzajúcimi odborníkmi na tej istej vzorke (Barba, Domínguez-Rodrigo 2006, 171). Ďalej G. Martínez (2009) uvádza vo svojom článku na základe vlastného recentného etnologického pozorovania nasledovné- stopy po žuvaní na vzorke kostí ko- ristí z kmeňa Nukak v Kolumbii, sú v 7 \% zastúpené u opíc, u prasiat pekarovitých žiadne stopy po zuboch nedokumentuje. $Z$ výsledkov ale prišiel $\mathrm{k}$ záveru, že najviac poškodení typických pre ludské zuby je spôsobených extrakciou špiku a že prípadné spracovanie mäsa, ako je pečenie či varenie, uberá na atraktivite koristi pre predátorov (Martínez 2009, 16). M.J. Landt (2004) sa zameriaval na stopy po konzumácii na kostiach malých cicavcov od členov kmeňa Bofi, ktorí žijú v rezervácii N'goto v pralesoch Centrálnej Afriky. Jedným $\mathrm{z}$ vyvodených záverov je, že $\mathrm{z}$ archeologického hladiska sú poškodenia, ktoré spôsobujú zuby mäsožravcov a hominidov vo svojej podstate rovnaké, aj ked'sa vzorovo líšia (Landt 2004, 121-122).

Popri paleoanropologických a etnoarcheologických štúdiách existuje niekolko prác, ktoré sú zamerané na experimentálne overenie ludského ohryzu v kontexte. D. Elkin a M. Mondini (2001) svoj experiment prevádzali medzi líškami (Pseudalopex gymnocerus) a lud'mi. Zámerom štúdie bolo poukázat na absenciu výskumov, ktoré sa venujú odlíšeniu stôp po zuboch stredne velkých predátorov a ludí. V závere udávajú, že viaceré znaky na kostiach boli spoločné pre obe skupiny konzumentov a ich lokalizácia bola tiež vo viacerých prípadoch podobná. Za zmienku stojí fakt, že v prípa- 


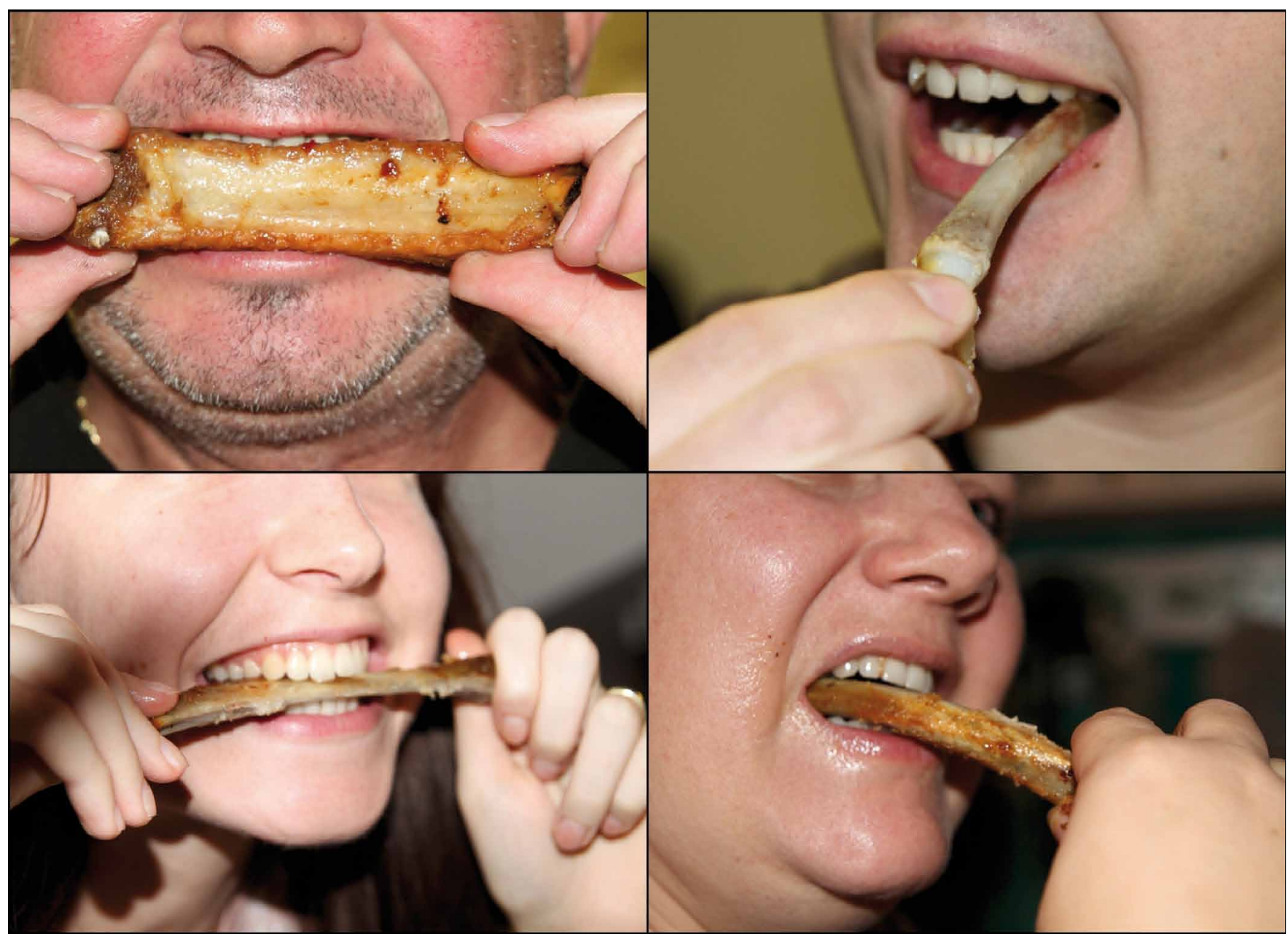

Obr. 2. Konzumácia rebier, súbor konkrétnych respondetov. Foto M. Stančíková.

de ludí sa povrchové znaky spojené s poškodením periostu a mäkkého tkaniva vyskytujú častejšie, ako u líšok (Elkin, Mondini 2001, 259). L. Lloveras et al. (2009) svoj experiment naopak zamerali na stopy po spracovaní, varení a jedení králika divého (Oryctolagus cuniculus) za pomoci kamenných nástrojov. Samotná konzumácia ale prebiehala bez akéhokolvek nástroja, práve pre zaistenie čo najvyššieho počtu autentických stôp. Bohužial', z celkového počtu kostí len 21,2 \% nieslo stopy po zuboch, najviac zastúpené boli na rebrách a pažnej kosti, menej na stavcoch a holennej kosti. Miesto ich výskytu bolo hlavne na telách rebier, proximálnych epifýzach dlhých kostí a na panve (Lloveras et al. 2009, 192). $\mathrm{Z}$ vyššie uvedeného preto vyplýva, že znalost’ stôp ludského ohryzu na kostennom materiále v kontexte d’alších podmienok a faktorov, akými sú napríklad kultúra či stravovacie návyky, obohacuje znalosti na poli archeológie či antropológie. Avšak v stredoeurópskom prostredí sa touto problematikou zaoberali práce len okrajovo, a preto $\mathrm{z}$ dôvodu absencie relevantnej štúdie sme sa rozhodli pre vlastný experiment s cielom dokumentácie a analýzy stôp ludského ohryzu na kostennom materiále.

\section{EXPERIMENTÁLNY DESIGN}

Výskumná vzorka kostí pozostávala z dvoch súborov. Prvý kontrolný súbor (obr. 1) obsahoval 38 okúsaných rebier svine domácej (Sus scrofa f. domestica) od 20 konkrétnych respondentov vo veku 20-50 rokov, so zastúpením oboch pohlaví a s rôznym stavom chrupu. Pred samotnou konzumáciou boli respondenti prvého súboru infomovaní o cieloch a rizikách experimentu.Tiež boli poučení o tom, aby očistili kosti čo najdôkladnejšie bez príboru s použitím vyššej sily skusu ako pri bežnej konzumácii. Súčasne boli požiadaní, aby pri okusovaní použili okrem rezákov aj čreňové zuby a stoličky (obr. 2). Druhý súbor obsahoval 40 náhodne vybraných rebier taktiež zo svine domácej od 20 anonymných jedincov rôzneho veku a pohlavia $\mathrm{z}$ dvoch bratislavských reštaurácií, ktorí o experimente neboli informovaní. Obom reštauráciám boli poskytnuté uzatváratel’né priehladné vrecká a na základe dohody s personálom každú porciu rebierok uložili do jedného vrecka. Z každého vrecka boli náhodne vybrané dve rebrá, ktoré boli zaradené do experimentu, zvyšok bol skartovaný. 

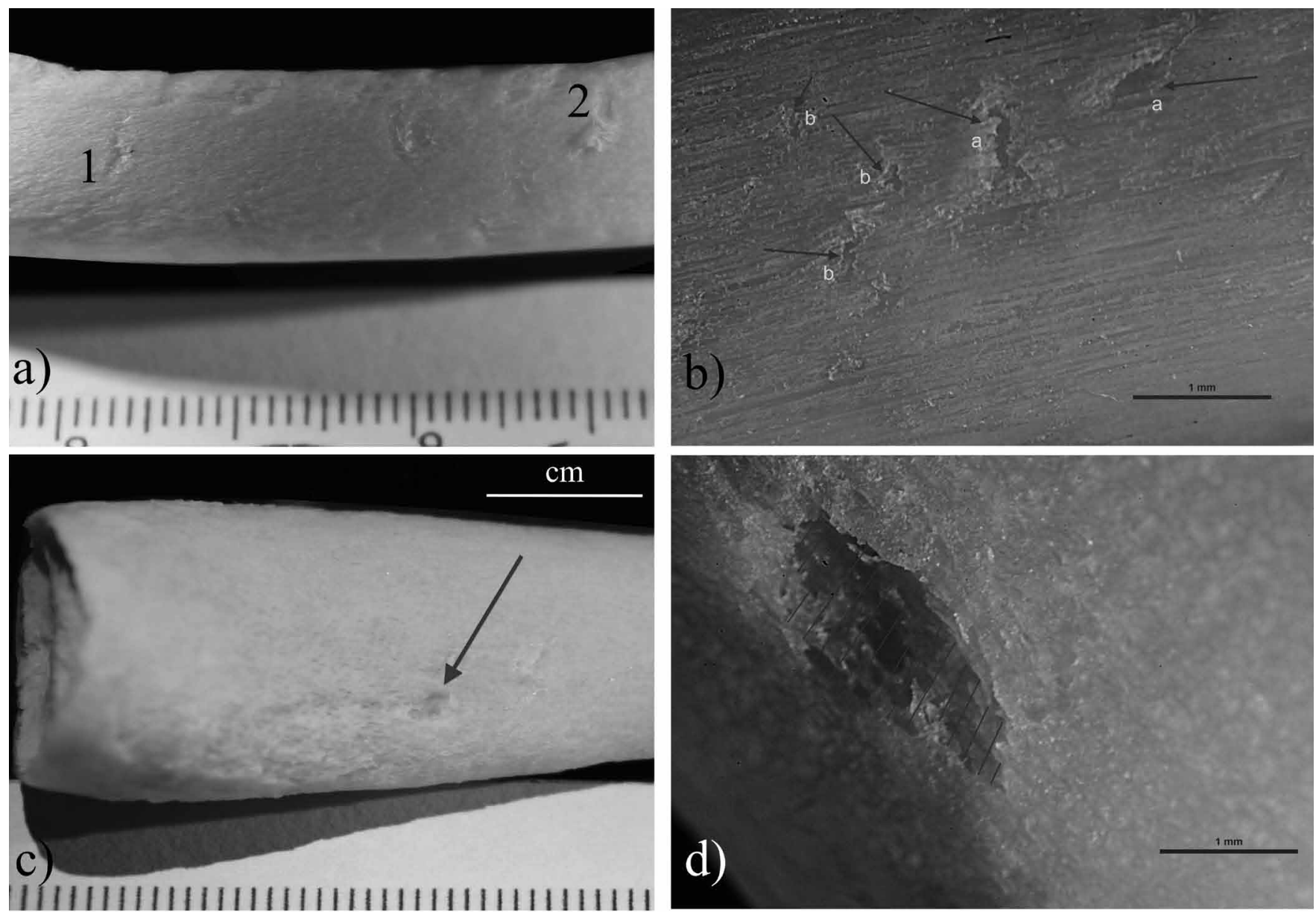

Obr. 3. Škrabanec (a1), jamka (a2) a vpich (c) na rebre svine domácej v skutočnej velkosti. Škrabance (b-a), jamky (b-b) a vpich (d) na rebre svine domácej, zväčšené 18x. Foto a grafická úprava M. Stančíková.

\section{METODIKA POPISU A VYHODNOTENIE MATERIÁLU}

\section{Čistenie a dokumentácia materiálu}

Kosti z oboch súborov boli následne šetrne očistené a vybielené peroxidom. Po vysušení boli kosti pozorované najprv volným okom a stolnou lupou typu Prós Kit MA-1205CB so zväčšením 2,25x a vstavaným LED osvetlením. Potom bola každá kost’ analyzovaná aj svetelným stereomikroskopom typu Nikon SMZ1500 pod zväčšením 18x v detašovanom pracovisku Archeologického ústavu AV ČR, Brno v Dolných Věstoniciach. Priebeh celého experimentu bol zaznamenávaný fotoaparátom Canon EOS 7D s objektívom Tamron AF $17-50 \mathrm{~mm}$. Fotografie zo stereomikroskopu boli zachytené fotoaparátom Nikon D7000.

\section{Charakteristika a vyhodnocovanie stôp}

Základné stopy, ktoré boli pozorované na oboch súboroch, vychádzajú z Binfordovej (1981) štúdie, v ktorej popisuje tieto tri základné kategórie, charakteristické pre kosti poškodené mäsožravcami a lud'mi - jamky (pits), vpichy (punctures) a škrabance (scores) (obr. 3). Jamky sú povrchové stopy spravidla spôsobené rezákmi (Andrews, Fernández-Jalvo 2011, 121), ktoré postrádajú pozdĺžnu osu (Andrews, Fer-

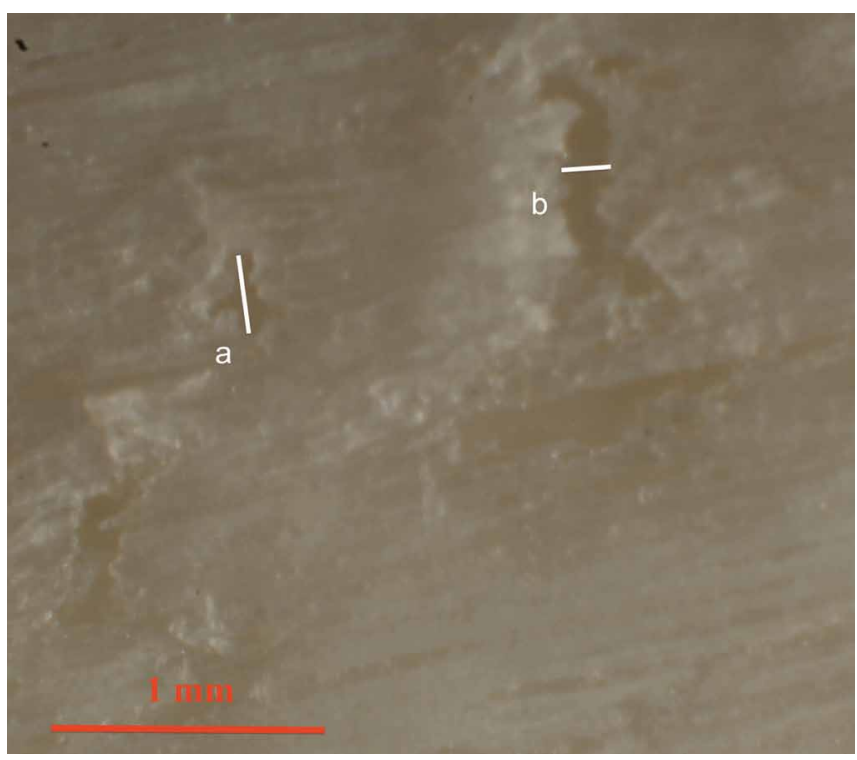

Obr. 4. Merané rozmery jamôk (a) a škrabancov (b) na rebre svine domácej. Foto a grafická úprava M. Stančíková. 


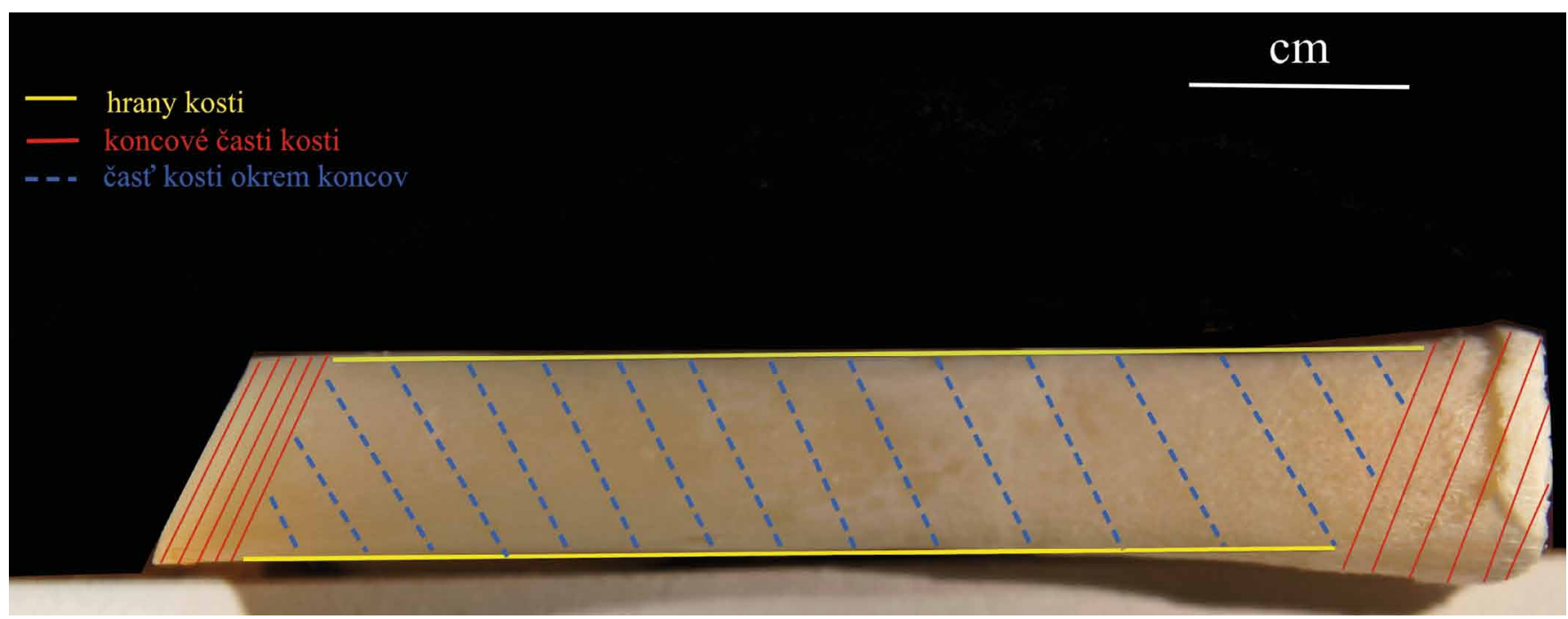

Obr. 5. Označenie plôch pre rozdelenie stôp do šiestich podkategórií na časti rebra svine domácej. Foto a grafická úprava M. Stančíková.

nandéz-Jalvo 1997, 192). Tento jav je u mäsožravcov bežný, viac spojený s extenzívne žuvanými kostami než so žraním a odrtŕhaním mäsa od kosti, ako je tomu pri zabití (Binford 1981, 46). Škrabance sú povrchové poškodenia, ktorých pozdĺžna osa je viac ako $4 \mathrm{x}$ dlhšia než priečna (Andrews, Fernandéz-Jalvo 1997, 192) a rovnako ako jamky sú spôsobené rezákmi (Andrews, Fernández-Jalvo 2011, 121). Ich dizajn je na prvý pohlad podobný so zásahmi noža, no na rozdiel od nich sú škrabance orientované takmer vždy trasverzálne na pozdľžnu osu kosti. Je to spôsobné tým, že vznikajú pri otáčaní kostí proti zubom, prípadne pri tahaní zubov po relatívne kompaktnej kosti (Binford 1981, 46). Vpichy naopak prerážajú povrchovú kompaktnú vrstvu a často zasahujú až do spongiózy (Binford 1981, 44). Sú trojuholníkového tvaru a ich výskyt je podmienený čreňovými zubami. Vznikajú pri ohybe koncov tenkých kostí a u ludí sú zriedkavo pozorované (Andrews, Fernández-Jalvo 2011, 121). Mimo týchto troch základných kategórií bola hodnotená aj prítomnost'/ neprítomnost' peelingu, ktorý White (1992) opisuje na príklade čerstvej vetvičky, ktorú ohneme až sa zlomí a obe jej časti ostanú visiet’ len na tenkom vlákne až kým ich neošúpeme. Ošúpanie na dreve zanecháva zdrsnený povrch s paralelnými žliabkami, ktorý je velmi podobný tomu na kosti, a vyskytuje sa na proximálnych a distálnych koncoch kostí (White 1992, 140-142).

Samotné meranie stôp ludského ohryzu prebehlo podla doporučení Landta $(2004,69,77)$. Pri jamkách a vpichoch bol meraný najdlhší priečny rozmer, pri škrabancoch najširší priečny rozmer (obr. 4). Pri viachrbolčekových zuboch boli merané dva rozmery podla Andrews a Fernández-Jalvo $(1997,192)$ a vynásobením najširšieho a najdlhšieho rozmeru bola potom vypočítaná celková plocha poškodenia. Stopy boli následne rozdelené do šiestich podkategórií podla typu a miesta poškodenia (obr. 5), z časti vychádzajúcich z Andrews a Fernández-Jalvo (1997, 192, 193):
1. Jamky, spôsobené rezákmi, nachádzajúce sa na kosti kdekolvek na povrchu okrem koncov;

2. Škrabance nachádzajúce sa na kosti kdekolvek na povrchu okrem koncov;

3. Vpichy na koncoch kostí;

4. Jamky spôsobené viachrbolčekovými zubami (stolička$\mathrm{mi}$, čreňovými zubami);

5. Vpichy na hranách rebier;

6. Škrabance na koncoch kostí.

Oproti uvedeným štúdiám boli počet redukovaný o tri dalšie kategórie, ktoré sú spájané so zlomením kosti, transverzálne či špirálovito, kedže takýto jav sa ani v jednom z našich súborov nevyskytoval. Naproti tomu bola pridaná kategória škrabancov na koncoch kostí. Okrem toho boli stopy rozdelené podla toho, či sa nachádzali na ventrálnej či dorzálnej strane rebra. Pri analýze boli sledované poškodenia dalej prerozdelené do podkategórií podla pravdepodobnosti pôvodu:

A. $99 \%$ ludské zuby (kategória pre oba súbory);

B. viac ako $60 \%$ ludské zuby (kategória pre oba súbory);

C. viac ako $60 \%$ iný pôvod - čistenie, porcovanie, varenie, (kategória pre oba súbory);

D. $99 \%$ nôž, spôsobené pri konzumácii (kategória pridaná len pre anonymný súbor).

Popri týchto stopách boli zaznamenané aj tie, ktoré nebolo možné zaradit do žiadnej z kategórií, ale bolo ich možné prisúdit konzumácii, vareniu či čisteniu.

\section{VÝSLEDKY ANALÝZY EXPERIMENTÁLNEHO SÚBORU}

Konkrétny súbor obsahoval celkom 38 kostí, z ktorých 30 kostí nieslo známky poškodenia, ktoré je možné interpretovat’ ako zásah ludskými zubami. Dokopy bolo v tomto súbore 
zaznamenaných 162 poškodení - t.j. 76 jamôk, 11 vpichov, 70 škrabancov a 5 párov jamôk spôsobených čreňovými zubami a stoličkami. Napriek tomu, že kvantifikácia zásahov z našich súborov nebola štatisticky významná, uvádzame priemerné rozmery týchto stôp za účelom základnej predstavy o tom, aká je velkost’ stôp spôsobených ludskými zubami, napríklad v porovnaní s inými živočíšnymi druhmi či nástrojmi. Priemerná velkost' jamôk predstavovala $1,75 \mathrm{~mm}$, najväčšia zameraná jamka dosahovala $4,69 \mathrm{~mm}$ a najmenšia mala velkost' $0,24 \mathrm{~mm}$. Viac ako polovica útvarov (celkom 47) sa pohybovala $v$ rozpätí od $0,6-2,0 \mathrm{~mm}$. Z hladiska pôvodu sú ludské zuby (podkategória A) s pravdepodobnostou $99 \%$ príčinou najväčšieho množstva poškodení (80 \%), medzi ktorými je takmer polovičné zastúpenie jamôk a škrabancov, naopak len $1 \%$ vpichov. $\mathrm{V}$ druhej podkategórii (B) je $12 \%$ poškodení spôsobených ludskými zubami, z toho polovicu tvoria jamky a rovné dve štvrtiny sú vpichy a škrabance. V podkategórii (C) pre tento súbor je $8 \%$ všetkých poškodení, najviac sú zastúpené jamky a vpichy, menej škrabance.

$\mathrm{V}$ anonymnom súbore, $\mathrm{z}$ celkového počtu 40 rebier, nieslo stopy poškodenia 10 kostí, celkovo bolo pozorovaných a zameraných 16 modifikácií. Najvýraznejším a najpočetnejším poškodením boli škrabance, ktoré sa vyskytli na kostiach celkom 15 krát, vpich bol zaznamenaný 1 a úplne absentovala kategória jamôk. Škrabance mali v priemere $0,36 \mathrm{~mm}$, najužší škrabanec mal $0,12 \mathrm{~mm}$, najširší nameraný rozmer bol $1,04 \mathrm{~mm}$. Najčastejšia šírka škrabancov (13) sa pohybovala v rozmedzí 0,1-0,5 mm. Jediný vpich mal rozmery $1,23 \mathrm{~mm}$. S $99 \%$ pravdepodobnostou (A) bol ludskými zubami spôsobený len 1 škrabanec. Do druhej podkategórie (B) bolo zaradených $19 \%$ poškodení, z toho $33 \%$ stôp tvoria vpichy, 67 \% škrabance. Až $75 \%$ všetkých poškodení je s pravdepodobnostou $99 \%$ iného pôvodu (D), všetky spadajú do kategórie škrabancov a boli pravdepodobne spôsobené príborovým nožom pri konzumácii.

\section{DISKUSIA A ZÁVER}

V nami sledovanej vzorke boli všetky tri základné typy poškodení, ktoré sú typické pre ludí a aj pre mäsožravce a to jamky, vpichy a škrabance (Binford 1981, 44; Andrews, Fernández-Jalvo 1997, 192). Všetky tri druhy poškodení bolo možné pomerne dobre sledovat' aj volným okom, mikroskopická analýza slúžila na utvrdenie a osvojenie si detailnej štruktúry jednotlivých stôp. Najväčší podiel tvorili škrabance a jamky, najmenej sa vyskytovali vpichy na hranách a koncoch a viacnásobné jamky spôsobené viachrbolčekovými zubami. Rozdrvený koniec, ktorý možno pripísat žuvaniu, bol pozorovaný iba jedenkrát. Takéto modifikácie súvisia s extrakciou kostnej drene a s jej vycucávaním, ktoré je známe z etnologických príkladov (Binford 1978, Martínez 2009, Fernández-Jalvo a Andrews 2011). Je možné predpokladat', že jedinci v slovenských skupinách nie sú zvyknutí vyciciavat kostnú dreň, počas konzumácie $\mathrm{v}$ kontrolnom súbore nebol pozorovaný nikto, kto by niečo také praktizoval. Tento fakt poukazuje na vysokú mieru variability v jedálnom habite v závislosti na kultúrnych

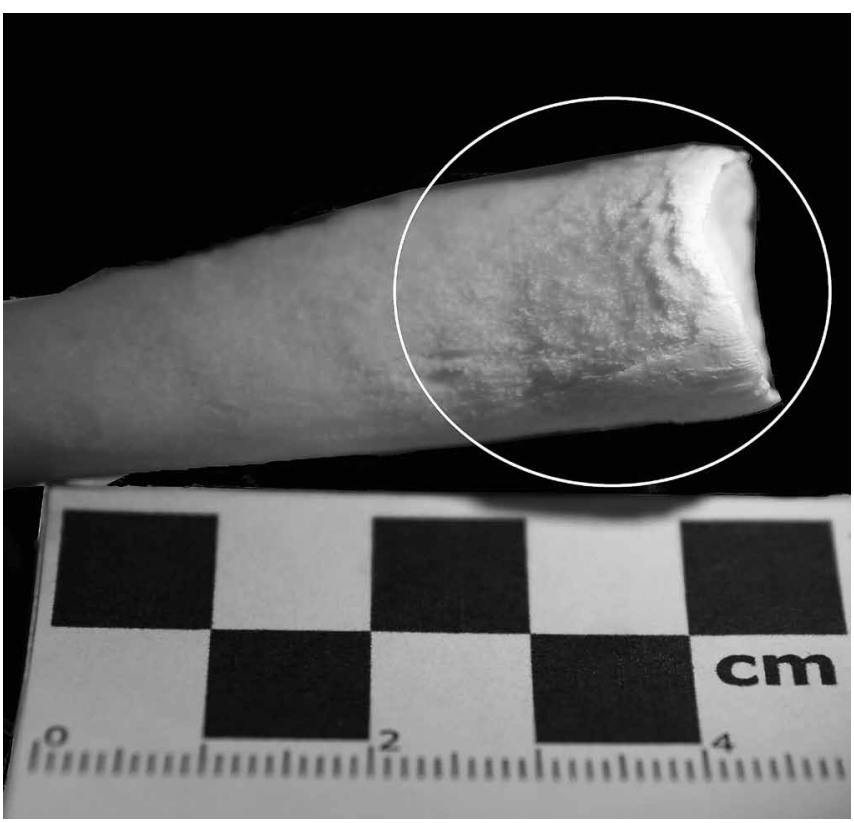

Obr. 6. Peeling sledovaný na koncovom úseku rebra, s najväčšou pravdepodobnostou spôsobený viacnásobnou tepelnou úpravou a čistením. Foto a grafická úprava M. Stančíková.

obyčajoch. Metrické hodnotenie, ktoré sme zahrnuli do vyhodnotenia experimentu v budúcnosti zjednoduší orientáciu $\mathrm{v}$ poškodeniach spôsobených nástrojmi a zubami, najmä v archeologickom kontexte. Výskyt peelingu (obr. 6) podla Whita (1992) bol zaznamenaný na 68 kostiach, v pomerne vel'kom rozsahu, v niekolkých prípadoch siahal od koncových oblastí $\mathrm{k}$ stredu kosti. Väčšie poškodenia niesli konce, ktoré mali epifýzu, na koncoch, ktoré boli odseknuté je peeling pozorovaný menej. Dá sa predpokladat', že jeho výskyt je podmienený $\mathrm{v}$ tomto experimente skôr niekolkonásobnou tepelnou úpravou a čistením ešte teplých kostí, ktoré mali mäkšiu štruktúru, čo zapríčinilo plošné odstránenie lamelárnej vrstvy, než súvislostou s ludským ohryzom.

$\mathrm{Z}$ anatomického hladiska boli stopy evidované na kostiach rozdelené podla výskytu na ventrálnej a dorzálnej strane. Výskyt poškodení bol porovnaný s Pickering et al. (2013), kde sú stopy tamer rovnomerne rozložené na oboch stranách kozích rebier, pričom o niečo málo prevláda ventrálna strana (52\%), nad dorzálnou (48\%). V prípade kontrolného súboru, ktorý niesol najviac poškodení, je distribúcia ludských stôp vyššia $\mathrm{v}$ prospech ventrálnej strany (64\%), čo môže byt' spôsobené tým, že je menej osvalená a lahšie prístupná, čím sa stáva náchylnejšou na poškodenie zubami pri konzumácii. V prípade anonymného súboru ide o pomer s menším rozdielom, otázkou však ostáva, či je distribúcia poškodení spôsobených nožom rovnaká, ako tá, ktorá je spôsobená zubami (graf 1). Výskyt poškodení bol najvyšší u kostí z kontrolného súboru, ktorý bol tvorený 20 európanmi. V porovnaní s inými experimentami (Fernández-Jalvo a Andrews 2011; Elkin, Mondini 2001; Lloveras et al. 2009; Landt 2004; Saladié et al. 2014), ktoré mapovali stopy ohryzu u rôznych jedincov, je toto čís- 
110

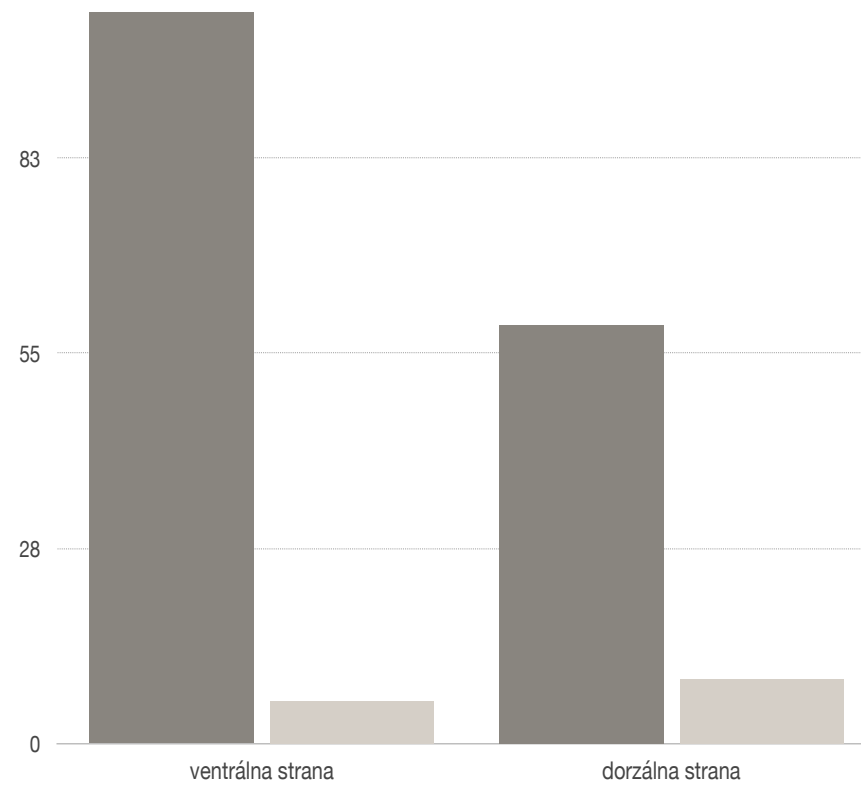

Graf 1. Stranové rozmiestnenie poškodení. Tmavosivou farbou sú označené poškodenia kontrolného súboru, bielou poškodenia anonymného súboru. Autorka grafu M. Stančíková.

lo o mnoho vyššie. Príčinou tak značne poškodeného súboru bola $\mathrm{v}$ tomto prípade neprítomnost' autenticity. Jedinci boli vopred informovaní o experimente a vedeli o jeho cieloch a zámeroch. Nejedná sa však o nevedomú chybu. Na tejto vzorke bolo možné sledovat viaceré typy modifikácií a ich variabilitu, čo bolo velmi nápomocné pri rozlišovaní stôp na kostiach anonymného súboru. Pozorovaná bola zaujímavá súvislost’ medzi kultúrou stolovania a mierou poškodenia. Jedinci, ktorí praktizujú spoločné stolovanie, častejšie navštevujú reštaurácie, a tak zvyšujú svoju kultúru stravovania, jedli bravčové rebrá menej dôkladne, čo v konečnom dôsledku viedlo $\mathrm{k}$ menšiemu počtu pozorovaných poškodení. Naproti tomu jedinci, ktorých jedálny habitus je jednoduchší, stravujú sa prevažne v domácnosti a preferujú jednoduché jedlá, konzumovali rebrá rýchlejšie a s väčším dôrazom. Zaujímavý bol tiež velmi nízky výskyt poškodení, ktoré patrili ludským zubom anonymného súboru (v porovnaní s Fernández-Jalvo a Andrews 2011, Lloveras et al. 2009). Jednou z interpretácií môže byt vyššia kultúra stolovania, kedže vzorka pochádzala z dvoch reštaurácií. Možno predpokladat', že ludia stravujúci sa práve v reštauráciách majú tendenciu siahnut po príbore častejšie a spoliehajú sa naň viac, ako na svoje zuby, práve zo spoločenských dôvodov a kvôli etikete.

Získané výsledky tak prispievajú k rozvinutiu témy stôp ludského ohryzu na kostennom materiále $\mathrm{v}$ stredoeurópskom kontexte. Napriek tomu, že je jedálny habitus súčasnej populácie silne ovplyvnený kultúrou, domnievame sa, že tento experiment prispeje $\mathrm{k}$ porozumeniu ludským ohryzom $\mathrm{v}$ archeologickom, antropologickom, ale aj forenznom kontexte, či už vo forenznej odontológii alebo v tafonómii.

\section{POĎAKOVANIE}

Táto štúdia vznikla za podpory špecifického vysokoškolského výskumu č. MUNI/1170/2015, ktorú poskytlo MŠMT. Autorky by chceli podakovat najmä všetkým respondentom a manažérom reštaurácií za ich ústretovost’ a ochotu zapojit sa do experimentu. Vd’aka patrí tiež recenzentom, za cenné pripomienky, ktoré prispeli k zlepšeniu úrovne tohoto textu.

\section{LITERATÚRA}

Andrews, P. - Fernandez-Jalvo, Y. (1997): Surface Modifications of the Sima de los Huesos Fossil Humans. Journal of Human Evolution, 33, 191-217.

Binford, L. R. (1978): Nunamuit Ethnoarchaeology. New York: Academic Press.

Binford, L. R. (1981): Bones. Ancient Men and Modern Myths. London: Academic Press, Inc.

Domínguez-Rodrigo, M. - Barba, R. (2006): New Estimates of Tooth Mark and Percussion Mark Frequencies at the FLK Zinj Site: the Carnivore Hominid Carnivore Hypothesis Falsified. Journal of Human Evolution, 50, 170-194.

Elkin, D. - Mondini, M. (2001): Human Small Carnivore Gnawing Damage on Bones an Exploratory Study and its Archaeological Implications. In: Kuznar, L.A. ed. Ethnoarchaeology of Andean South America; Contributions to Archaeological Method and Theory. International Monographs in Prehistory.

Fernandéz-Jalvo, Y. - Andrews, P. (2011): When human chew bones. Journal of Human Evolution, 60, 117-123.

Landt, M. J. (2004): Investigations of human gnawing on small mammal bones: Among contemporary Bofi foragers of the Central African Republic. Magisterská práca. Washington: Washington State University.

Lloveras, L. - Moreno-García, M. - Nadal, J. (2009): Butchery, Cooking and Human Consumption Marks on Rabbit (Oryctolagus cuniculus) Bones: An Experimental Study. Journal of Taphonomy, 7 (2-3), 179-201.

Martínez, G. (2009): Human Chewing Bone Surface Modification and Processing of Small and Medium Prey Amongst the Nukak (Foragers of the Colombian Amazon). Journal of Taphonomy, 7 (1), 1-20.

Pickering, T. R. - Domínguez-Rodrigo, M. - Heaton, J. L. - Yravedra, J. - Barba, R. - Bunn, H. T. - Musiba, Ch. - Baquedano, E. - Diez-Martín, F. - Mabulla, A. - Brain, C. K. (2013): Taphonomy of ungulate ribs and the consumption of meat and bone by 1.2-million-year-old hominins at Olduvai Gorge, Tanzania. Journal of Archaeological Science (40), 1295-1309.

Pobiner, B. (2008): Paleoecological Information in Predator Tooth Marks. Journal of Taphonomy, 6 (3-4), 373-397.

Saladié, P. - Rodríguez-Hidalgo, A. - Huguet, R. - Cáceres, I. - Diéz, C. Vallverdú, J. - Canals, A. - Soto, M. - Santander, B. - de Castro, J. M. B. - Arsuaga, J. L. - Carbonell, E. (2014): The role of carnivores and their relationship to hominin settlements in the TD6-2 level from Gran Dolina (Sierra de Atapuerca, Spain). Quaternary Science Reviews, 93, 47-66.

White, T. D. (1992): Prehistoric Cannibalism at Mancos 5MTUMR-2346. Princeton University press.

\section{AUTORKY}

Michaela Stančíková Bc. Študentka magisterského stupňa v odbore Antropológia na MU v Brne. V súčasnosti vo svojej diplomovej práci naväzuje na výskum stôp ludského ohryzu na kostennom materiále, so zameraním na stopy ohryzu šeliem a prasiat.

Kontakt: Michaela Stančíková Bc., Ústav antropologie Přírodovědecké fakulty Masarykovy univerzity, Kotlářská 2, 61137 Brno,

E-mail: 394245@mail.muni.cz 
Sandra Sázelová Mgr. Ph.D. Odborná asistentka Ústavu antropologie PřF MU a Střediska pro výzkum paleolitu a paleoetnologie Archeologického ústavu AVČR Brno - detašované pracovisko v Dolních Věstonocích. Z odbornej činnosti sa zameriava na paleoantropológiu, etnoarcheológiu a komparatívnu osteológiu; svoje výsledky prezentovala na viac než dvoch desiatkach českých i zahraničných konferenciách a $\mathrm{v}$ sérii impaktovaných a recenzovaných článkov, napr. v časopisoch Quaternary International, Human Ecology, Ar- chaeology, Ethnology and Anthropology in Eurasia či Archäeologisches Korrespondentzblatt.

Kontakt: Sandra Sázelová Mgr. Ph.D.

Ústav antropologie Př́rodovědecké fakulty Masarykovy univerzity, Kotlářská 2, 61137 Brno a Středisko pro paleolit a paleoetnologie Archeologického ústavu AVČR, Brno, Dolní Věstonice 25, 69129

Dolní Věstonice, E-mail: sazelova@sci.muni.cz 